\title{
Generating strategies with KPIs (Key Performance Indicators) through the use of TIC's (Information and Communication Technologies)
}

\section{Generando estrategias con KPI's (Indicadores Clave de desempeño) mediante el uso de TIC's (Tecnologías de Información y Comunicaciones)}

\author{
CASTORENA-PEÑA, Jesús Abraham ${ }^{1} \dagger$, SILVA-AVILA, Alicia Elena ${ }^{1}$, GONZÁLEZ BENÍTEZ, \\ Rubén Álvaro ${ }^{2}$, MARTÍNEZ CASTRO, Jehú Efraín ${ }^{1}$
}

${ }^{1}$ Universidad Autónoma de Coahuila. Barranquilla s/n, Col. Guadalupe C.P.25750

${ }^{2}$ Universidad Veracruzana. Circuito Gonzalo Aguirre Beltrán s/n, Zona Universitaria. C.P. 91000

ID $1^{\text {st }}$ Author: Jesús Abraham, Castorena-Peña / ORC ID: 0000-0002-8833-1159, CVU CONACYT ID: 411532

ID $1^{\text {st }}$ Coauthor: Alicia Elena, Silva-Avila / ORC ID: 0000-0001-7093-9898, CVU CONACYT ID: 260461

ID $2^{\text {nd }}$ Coauthor: Ruben Álvaro, González-Benitez / ORC ID: 0000-0002-6396-0100, CVU CONACYT ID: 64051

ID $3^{\text {rd }}$ Coauthor: Jehú Efraín, Martínez-Castro / ORC ID: 0000-0002-4151-947X

\begin{abstract}
Organizations are facing an uncertain scenario due to business dynamics and the evolution of their technical terminology to adapt to new ways of competing in the environment, which requires assertive indicators to ensure permanence and success in the medium and long term of any company. Through the use of KPIs, organizations have the opportunity to analyze and monitor relevant information from their company to make the operations of a company's sales area more efficient. The objective of this study is to propose a set of key performance indicators (KPI's) that allow the performance of a company dedicated to the activity of commercialization and manufacture and import of cleaning products to be measured, which is analyzed using the monetary variables of units or percentages. For the development of the investigation, Microsoft SQL Server was used as technological tools for the creation of the data model, and for the design, construction and analysis of the KPIs, the BSC Designer tool was used.
\end{abstract}

KPI's, PyMES, SQL Server, BSC Designer

\begin{abstract}
Resumen
Las organizaciones se encuentran ante un panorama poco incierto debido a la dinámica de los negocios y a la evolución de su terminología técnica para adaptarse a las nuevas formas de competir en el entorno, el cual amerita de indicadores asertivos para asegurar la permanencia y éxito a mediano y largo plazo de cualquier compañía. Mediante el uso de KPI's las organizaciones tienen la oportunidad de analizar y monitorear información relevante de su compañía para hacer más eficientes las operaciones del área de ventas de una empresa. El objetivo del presente estudio es proponer de manifiesto un conjunto de indicadores claves de desempeño (KPI's) que permita medir el rendimiento de una empresa dedicada a la actividad de comercialización y fabricación e importación de productos de limpieza, la cual es analizada mediante las variables monetaria de unidades o porcentajes. Para el desarrollo de la investigación se utilizó como herramientas tecnológicas Microsoft SQL Server para la creación del modelo de datos, y para el diseño, construcción y análisis de los KPI's se utilizó la herramienta BSC Designer.
\end{abstract}

KPI's, PyMES, SQL Server, BSC Designer

Citation: CASTORENA-PEÑA, Jesús Abraham, SILVA-AVILA, Alicia Elena, GONZÁLEZ-BENÍTEZ, Rubén Álvaro and MARTÍNEZ-CASTRO, Jehú Efraín. Generating strategies with KPIs (Key Performance Indicators) through the use of TIC's (Information and Communication Technologies). Journal of Bussines Development Strategies. 2020. 6-17: 1-6.

$\dagger$ Researcher contributing first author. 


\section{Introducction}

Currently, organizations affected by a series of challenges due to the changes determined by the environment and the emergence of new rivals, that is why companies need to continuously and quickly adapt their business strategies in such a way that they can optimize your processes to stay competitive and grow favorably in the markets. For which, they must generate the necessary mechanisms to fulfill the goals set by the organization, which implies the definition, design and structuring of a series of indicators that allow the evaluation of the fundamental aspects to achieve the success of the companies. In this line Sánchez (2003), finds that in micro and small and medium-sized enterprises (SMEs) there are no objectives (strategy, vision and objectives), strategies, action plans and performance indicators that allow successful achievement. of their strategies.

For this reason, the relevant result that is within micro-enterprises and SMEs will be the implementation of key performance indicators (KPIs), since they are a measurement tool that offers a series of advantages, to focus management efforts. on key areas of performance and quantify compliance with the strategic objectives established by the organization, among others.

KPIs provide a quick and condensed overview of a company's actual and objective performance, as well as enabling continuous control, communication, and improvement of its processes (Bassen \& Kovács, 2008). These measures also represent an essential management tool because they are used to quantify important data based on the performance and performance of organizations (Casas, 2015).

Having a measurement system expands opportunities for evaluating past and present performance, as well as thinking about future strategies that can strengthen the company's organizational and professional growth (Madroñal, Galeano and Escobar, 2016).
According to Rodríguez, Alfaro and Ortiz (2009), a performance measurement system allows managed companies to make decisions based on strategies, due to information on whether or not the established objectives are being achieved. For Velimirovića, Velimirovićb and Stankovića, (2011) KPIs represent financial and nonfinancial measures that organizations have to monitor how successful they were in achieving their stated objectives. To constitute an effective performance measurement system, it is very important to have defined and standardized all the processes within the organization, since this will depend on its successful implementation. Also, according to Ferry, Murphy, Zakaria and Zakaria (2015) argue that the implementation of KPIs needs strong support, both human and non-human, for their introduction to be effective within organizations.

KPIs have become a crucial support tool for organizations today, because through these indicators companies have the opportunity to effectively identify, monitor and measure the performance of their processes. However, there is still an absence of this type of indicator within certain industrial sectors, such is the case of the commercialization, manufacturing and import sector of cleaning products. For this reason, the following research is presented, which aims to propose a set of key performance indicators (KPIs) for the sales process of SMEs in the sector of commercialization, manufacture and import of cleaning products, in order to provide assertive information and evaluate the effectiveness of the sales process leading to the fulfillment of the organization's strategic objectives.

\section{Methodology}

For the development of this study, we had access to a company dedicated to the activity of commercialization, manufacture and import of cleaning products. For this, information was requested regarding its mission, vision, strategic objectives and information on its main activities, focusing solely on the company's sales area. Once the information was obtained, an analysis of the sales process was carried out to define, design and structure the main performance indicators that would control and monitor the performance of said area. 


\section{Construction and implementation of the data model for the generation of KPI's}

Modeling and building the sales process, we proceeded to load the data into the created database, which was designed using the ascending modeling strategy, this model consists of starting with a list of all the attributes of the data model, the requirements are decomposed, independently conceptualized and finally merged into a global scheme (Garrido, 2014). Resulting in the final model (Figure 1) which will house the transformed data from the previous stage for the analysis and extraction of the KPI's.

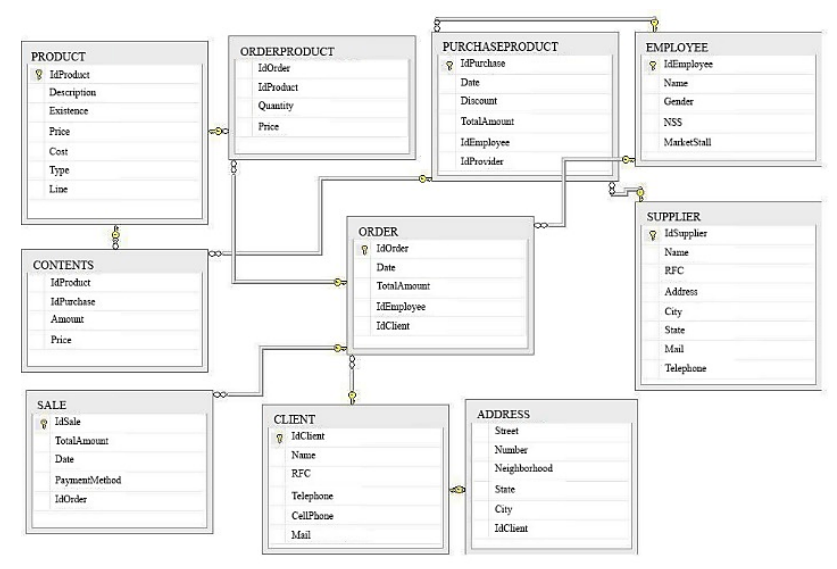

Figure 1 Data model of the sales process Source: own elaboration

\section{Definition and Construction of KPI's}

The construction of the KPI's was developed to establish the main performance indicators that would allow a diagnosis and monitoring of the activities and sales processes of the company, in such a way that this would serve as support for the creation and design of a table of integral command in the future. For the construction of the KPIs, the BSC Designer Software was used, which is a business performance management system that focuses on the Balanced Scorecar concept, allowing the creation and monitoring of KPIs, strategic maps and reports (Maya, 2016 ). It also offers the possibility of making a quick analysis of the indicators and forecasting the behavior of their values in a certain time, keeping the company informed about the most important changes in their KPIs. Next, the design and the values obtained using the technological tool are shown (Figure 2).

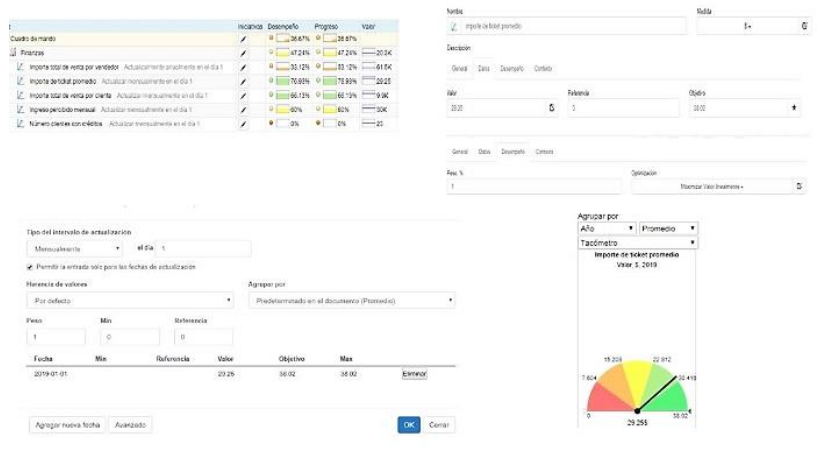

Figure 2 Construction of the KPI "Average ticket amount"

Source: own elaboration

\section{Results}

The results obtained are presented below, which correspond to a set of key performance indicators (KPI's) to monitor and measure the performance of the sales process of the company in question. The indicators designed are based on the strategic objectives of the company and the exploitation of the sales process database.

To drive the increase in the amount of sales within the company, three KPIs were defined which will be able to generate profitability and market value for the company over time.

- Total amount of sale per seller. This indicator represents the total sold per employee within the company. Which was considered, because the company does not have a balance in the sellers' client portfolio (Graph 1). Likewise, we propose to balance this portfolio by setting biweekly sales goals.

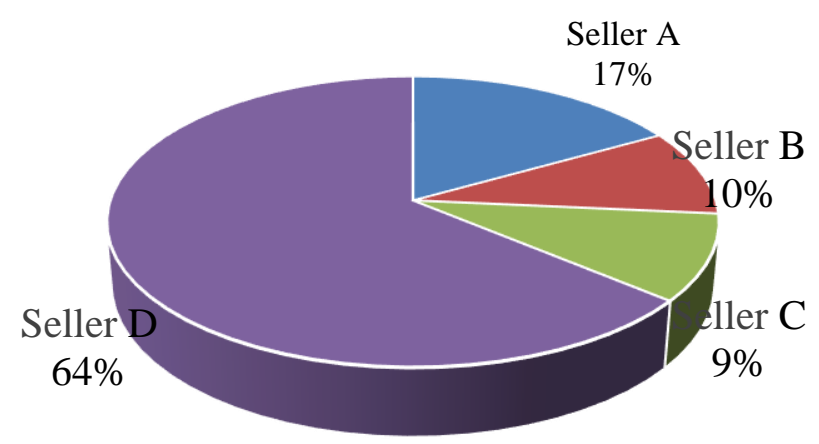

Graphic 1 Total sales per seller Source: own elaboration 
- Average ticket amount. The following measurement is obtained based on the number of transactions made from retail and wholesale sales (Graphic 2). So it is relevant to take advantage of the 2577 retail visits and establish sales work strategies to increase them.

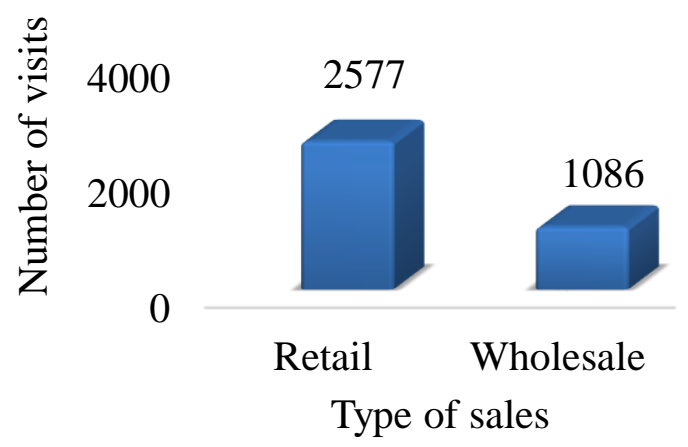

Graphic 2 Number of customers by retail and wholesale Source: own elaboration

- Total sales amount per potential customer. This represents the total consumed by customers who are characterized by not making frequent purchases in the company and who are likely to become potential customers who can increase their purchases.

\begin{tabular}{|l|r|}
\hline Client & \multicolumn{1}{|c|}{ Total (\$) } \\
\hline Client A & 10918.07 \\
\hline Client B & 9065.42 \\
\hline Client C & 10447.64 \\
\hline Client D & 9252.92 \\
\hline
\end{tabular}

Table 1 Total sale amount between $\$ 8500$ and $\$ 11000$ per potential customer

Source: own elaboration

Regarding the company's liquidity increase, only one key performance indicator was defined:

- Monthly income. This measurement represents the total sold per month. Which will identify those months that are below the average of total sales $(\$ 50,000)$ and thus, be able to generate sales strategies in those months for their increase and that the company does not lack cash flow.

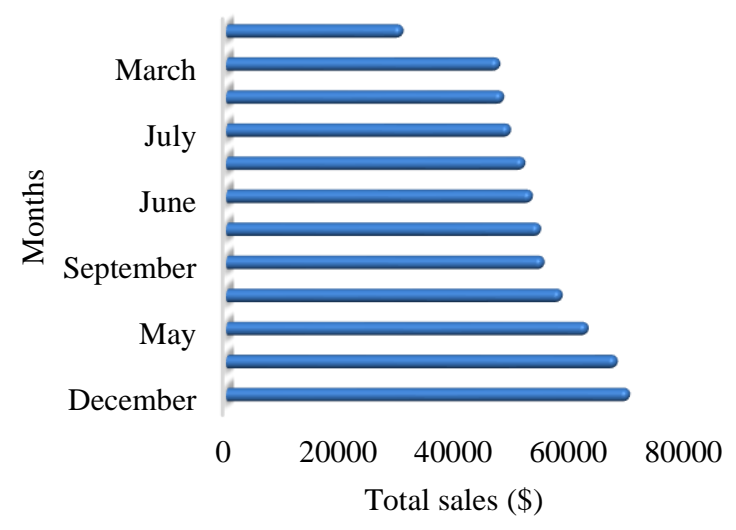

Graphic 3 Total monthly sales

Source: own elaboration

While, to increase the value of the brand, which refers to the products manufactured by the company, it is proposed to measure the total number of products sold by each type of product. For which the following KPI was defined:

- Number of products manufactured. This indicator represents the total number of products manufactured by the company sold, with the purpose of promoting the increase in sales of manufactured products with respect to marketing and import products (Graphic 4).

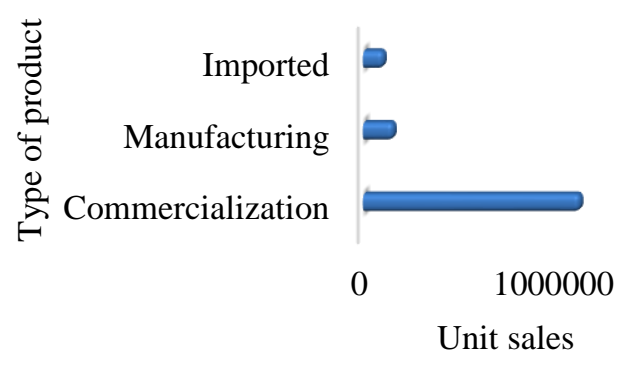

Graphic 4 Total sold by product type Source: own elaboration

On the other hand, to increase the presence of the company in different states of the Mexican Republic, the following indicator is proposed:

- Number of potential states. This measure represents the number of states in which the company has a presence in the Mexican Republic (Table 2). 


\section{Total states}

\section{5}

Table 2 Number of states with presence in the Mexican Republic

Source: own elaboration

And finally, to increase alliances with new suppliers that allow a secure supply and constant flow of products, the following indicator was established:

- Number of items sold. This measurement indicates the total number of best-selling items in the company.

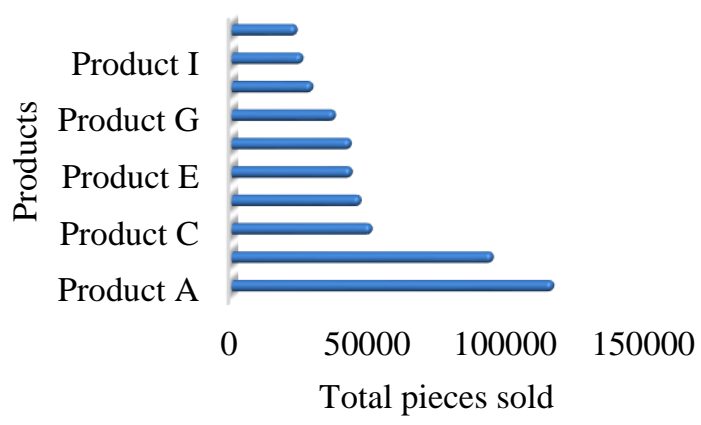

Graphic 5 Top 10 best-selling products Source: own elaboration

\section{Conclusions}

A company is a system with organized or related parts or elements that interact with each other to reach the same objective. And to achieve this, it is essential to have a series of key performance indicators that allow you to evaluate and review the fulfillment of the organization's strategic objectives, so that you can review the current performance of your sales processes and think about future strategies in if so required. Likewise, it is relevant to have a trustworthy structured database system that supports KPIs for their correct monitoring and behavior, as well as facilitating the visualization and analysis of relevant data to determine objectives that drive the organizational and personal growth of SMEs in the commercialization, manufacturing and import sector of cleaning products.

\section{Acknowledgments}

The facilities provided to carry out this article are grateful to the Autonomous University of Coahuila.

\section{References}

Bassen, A., \& Kovács, A. (2008). Environmental, social and governance key performance indicators from a capital market perspective. Zeitschrift fuer Wirtschafts- und Unternehmensethik, 9(2), Pp. 182-192. Obtenido de https://pdfs.semanticscholar.org/07bb/4ae06442 6364afedb48a3081d90d80d4a910.pdf

Casas, J. S. (2020). Diseño de tableros de control de indicadores para el análisis de la información acerca de la situación de los graduados de la Institución Universitaria Politécnico Grancolombiano mediante el uso de Microsoft Power BI.

Ferry, L., Murphy, P., Zakaria, Z., \& Zakaria, Z. (2015). Implementing Key Performance Indicators in a government agency : a typical story? Journal of Finance and Management in Public Services, 14, Pp. 2-15.

Garrido, B.S., Diseño de Bases de Datos - Un enfoque práctico. Edición Kindle, 2014.

Madroñal, M., Galeano, B., \& Escobar, N. (2016). Búsqueda de KPIs de Facility Management para administrar la infraestructura hospitalaria en Colombia. Revista Ingeniería Biomédica, 10(20), Pp. 13-19. Retrieved from http://www.scielo.org.co/pdf/rinbi/v10n20/v10n 20a02.pdf

Maya, R. A. (2016). Performance Management for Syrian Construction Projects. International Journal of Construction Engineering and Management, 5(3), Pp. 65-78. doi:10.5923/j.ijcem.20160503.01

Rodriguez, R., Alfaro, J. J., \& Ortiz, A. (2009). Quantitative relationships between key performance indicators for supporting decisionmaking processes. Computers in Industry, 60, Pp. 104-113. doi:https://doi.org/10.1016/j.compind.2008.09.0 02 
Sánchez , J. (2003). Estrategia integral para PyMES innovadoras. Revista Escuela de Administración de Negocios(47), Pp. 34-45. Obtenido de https://www.redalyc.org/pdf/206/20604703.pdf

Velimirović, D., Velimirović, M., \& Stanković, R. (2011). Role And Importance Of Key Performance. Serbian Journal of Management, 6 (1), Pp. 63 - 72. Obtenido de http://www.sjm06.com/SJM\%20ISSN14524864/6_1_2011_May_1-121/6_1_63-72.pdf 